\title{
Ant communities (Hymenoptera: Formicidae) in an urban ecosystem near the Atlantic Rainforest
}

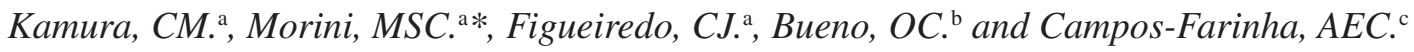 \\ ${ }^{a}$ Núcleo de Ciências Ambientais, Universidade de Mogi das Cruzes - UMC, \\ Av. Dr. Cândido Xavier de Almeida e Souza, 200, CEP 08780-911, Mogi das Cruzes, SP, Brazil \\ ${ }^{\mathrm{b}}$ Centro de Estudos de Insetos Sociais, Instituto de Biociências de Rio Claro - UNESP, \\ CEP 13506-900, Rio Claro, SP, Brazil \\ ${ }^{\mathrm{c}}$ Centro de Pesquisa e Desenvolvimento de Sanidade Vegetal, Instituto Biológico, \\ Av. Conselheiro Rodrigues Alves, 1252, CEP 04014-002, São Paulo, SP, Brazil \\ *e-mail: morini@umc.br
}

Received August 22, 2005 - Accepted June 12, 2006 - Distributed November 30, 2007

(With 6 figures)

\begin{abstract}
The relationships between an urban ecosystem located near the Atlantic Rainforest in southeastern Brazil and ant communities were studied with the objective of quantifying the ant richness and abundance in the household environment and its surroundings. Eighty residences were sampled, where 58 species and 28 genera pertaining to 7 subfamilies were found to be present. Inside the residences, the species richness was found to be lower (26), although the abundance was greater $(10,670)$, with the wash area and kitchen being the locales that contributed with the greatest number of hits. The opposite was true in the areas outside the residences, where 54 species and 3,747 ants were observed. Inside houses, the species known as Tramp ants were found, in the following order of importance: Solenopsis saevissima, Tapinoma melanocephalum, Linepithema humile, Paratrechina fulva, Wasmannia auropunctata, P. longicornis, Pheidole megacephala, Monomorium pharaonis and M. floricola. Externally, mainly in the yards and gardens, species such as Octostruma rugifera, Heteroponera dolo, Hypoponera sp.1 and sp.6, Gnamptogenys sp. 4, G. striatula, Odontomachus meinerti, Pachycondyla constricta and P. striata were found. In general, a greater number of species and lower abundance of individuals were observed in the neighborhoods nearer the mountains than in those closer to the urban center.
\end{abstract}

Keywords: Atlantic Rainforest, Tramp ants, species richness, communities, Formicidae, urbanization.

\section{Comunidades de formigas (Hymenoptera: Formicidae) em um ecossistema urbano próximo à Mata Atlântica}

\begin{abstract}
Resumo
A relação entre um ecossistema urbano localizado próximo à Mata Atlântica na região sudeste do Brasil e as comunidades de formigas foi estudada com o objetivo de quantificar a riqueza e a abundância de formigas no interior e no entorno das residências. Oitenta casas foram amostradas, tendo sido encontradas 58 espécies e 28 gêneros pertencentes a 7 subfamílias. No interior das residências foi encontrada uma baixa riqueza de espécies (26) e um alto número de indivíduos (10.670), sendo a área de serviço e a cozinha os locais que mais contribuíram para esse resultado. Já no entorno das residências foram encontradas 54 espécies e 3.747 indivíduos. No interior das casas, as espécies conhecidas como "Tramp - ants" foram encontradas na seguinte ordem de importância: Solenopsis saevissima, Tapinoma melanocephalum, Linepithema humile, Paratrechina fulva, Wasmannia auropunctata, P. longicornis, Pheidole megacephala, Monomorium pharaonis e M. floricola. Externamente, principalmente no jardim e quintal, foram encontradas espécies como: Octostruma rugifera, Heteroponera dolo, Hypoponera sp.1 e sp.6, Gnamptogenys sp.4, G. striatula, Odontomachus meinerti, Pachycondyla constricta e P. striata. Em geral, o maior número de espécies e baixa abundância de indivíduos foram observados em bairros próximos às áreas de mata.
\end{abstract}

Palavras-chave: Mata Atlântica, formigas andarilhas, riqueza, Hymenoptera, Formicidae, urbanização. 


\section{Introduction}

Urban ecosystems are generally recognized as being areas undergoing profound and constant local human activity, composed of high-density human habitation, industrial and commercial centers (McIntyre et al., 2001). The environmental modifications that occur during the process of urbanization can affect the distribution of organisms in diverse ways. For example, in this environment, many species achieve high densities, and assume dominant positions due to the existence of unoccupied niches, absence of competitors, and few natural enemies (Luck and Dahsten, 1974); or the intentional and unintentional introduction of exotic species can cause the dislocation of native species (Suarez et al., 1998; Crooks and Soulé, 1999). Yamaguchi (2004, 2005), studying the influence of urbanization on ant distribution in parks, suggested that these insects would become the bio-indicators of variation in urban environments.

Some ant species have successfully occupied urban environments, achieving wide distribution and abundance. This success is probably related to their feeding habits, as the majority of ants is omnivorous, and also because they exploit small spaces for nesting, such as crevices and holes. Human contact with ants in the urban environment can be observed in residences, commercial establishments, and even in hospitals. In houses, ants cause discomfort, whereas in hospitals, they can carry pathogenic organisms (Eichler, 1978; Bueno and Campos-Farinha, 1999).

In Brazil, the process of urbanization is occurring at an accelerated pace, and often advancing on areas that are considered to be priorities for conservation. This is the case of the city of Mogi das Cruzes, located in southeastern Brazil, where the urban network is centered around the ciliary plants of the Tietê River, and is expanding in the direction of the Itapety and Serra do Mar mountains, which belong to the Atlantic Rainforest biome. To maintain urban biodiversity for inhabitants, and because of it intrinsic value in the face of increasing population and urban growth, knowledge regarding the ecology of the species in these locales is needed.

Thus, the present study seeks to quantify the richness and abundance of ants in the household environment and its surroundings, with the objective of determining the communities that occur in an urban ecosystem characterized by its proximity to the Atlantic Rainforest, to compare this ecosystem with other urban areas.

\section{Material and Methods}

\subsection{Study site}

The city of Mogi das Cruzes, São Paulo, is the largest city in the Tietê-cabeceiras hydrological basin, of $731 \mathrm{~km}^{2}$ and with 330,000 inhabitants. It has the second largest forest covering in the Atlantic Rainforest, 17,100 ha, located mainly in the proximity of the Serra do Itapety and Serra do Mar mountains, along the Tietê River.
The collection was conducted in 16 neighborhoods in the city, with the northernmost neighborhoods being close to the Serra do Itapety $\left(23^{\circ} 29^{\prime} 22^{\prime \prime} \mathrm{S}\right.$ and $46^{\circ} 11^{\prime} 55^{\prime \prime} \mathrm{W}$; $800 \mathrm{~m}$ above the sea level), and those in the south approximating the Serra do Mar (23 45' 02" S and 46 $07^{\prime} 63^{\prime \prime} \mathrm{W}$; $720 \mathrm{~m}$ above the sea level) (Figure 1).

\subsection{Ant collection}

In each neighborhood, 5 houses were randomly sampled. The collections were conducted every two months for a period of 12 months, always in the same houses. The bait was made from dehydrated beef liver, honey, pineapple cake, and peanut oil, according to the recipe and following the methodology proposed by Bueno and Campos-Farinha (1999). Small amounts of fresh bait were placed inside beverage straws $0.5 \mathrm{~cm}$ in diameter and $2 \mathrm{~cm}$ long. In the interiors of the houses (household environment), 8 baits were placed: 3 in the kitchen, 2 in the bathroom, and 3 in the wash area. The baits were removed after 24 hours and placed in plastic bags. Manual collections were also conducted around the outside of the houses (walls, gardens, garage, and yard).

The material was initially identified according to morpho-species within genera. The identification of the species was carried out by comparison with the ant collections at the Museu de Zoologia of Universidade de São Paulo and the Coleção Entomológica Adolph Hempel (Instituto Biológico), as well as with the pertinent literature. Classification follows Bolton (2003). Vouchers were deposited at the University of Mogi das Cruzes (SP).

\section{Data Analysis}

Species richness was defined as the number of ant species occurring in each house, and abundance as the number of individuals collected of each species. The Wilcoxon test, using GraphPad Prism 3.0 software, was applied to test for significant differences between species richness, as well as between the number of individuals inside and outside the houses. Similarity between the interior and exterior of the houses was calculated using the Jaccard index (Magurran, 1988). The relative frequency was calculated based on presence or absence date, and the matrix of association between species with more than $3 \%$ frequency was done using the Spearman correlation test (Siegel, 1975).

\section{Results and Discussion}

In 80 samples, 14,417 specimens were collected, distributed among 58 species and 28 genera pertaining to 7 Sub-families. The sub-family Myrmicinae was the most represented, with 35 species and 15 genera, as well as the most abundant, with 9,588 ants. The genus richest in species was Pheidole (13), followed by Camponotus (5) and Solenopsis (4) (Figure 2). The species with the greatest relative frequency and abundance, according to the area of the residence sampled, are presented in Table 1. 


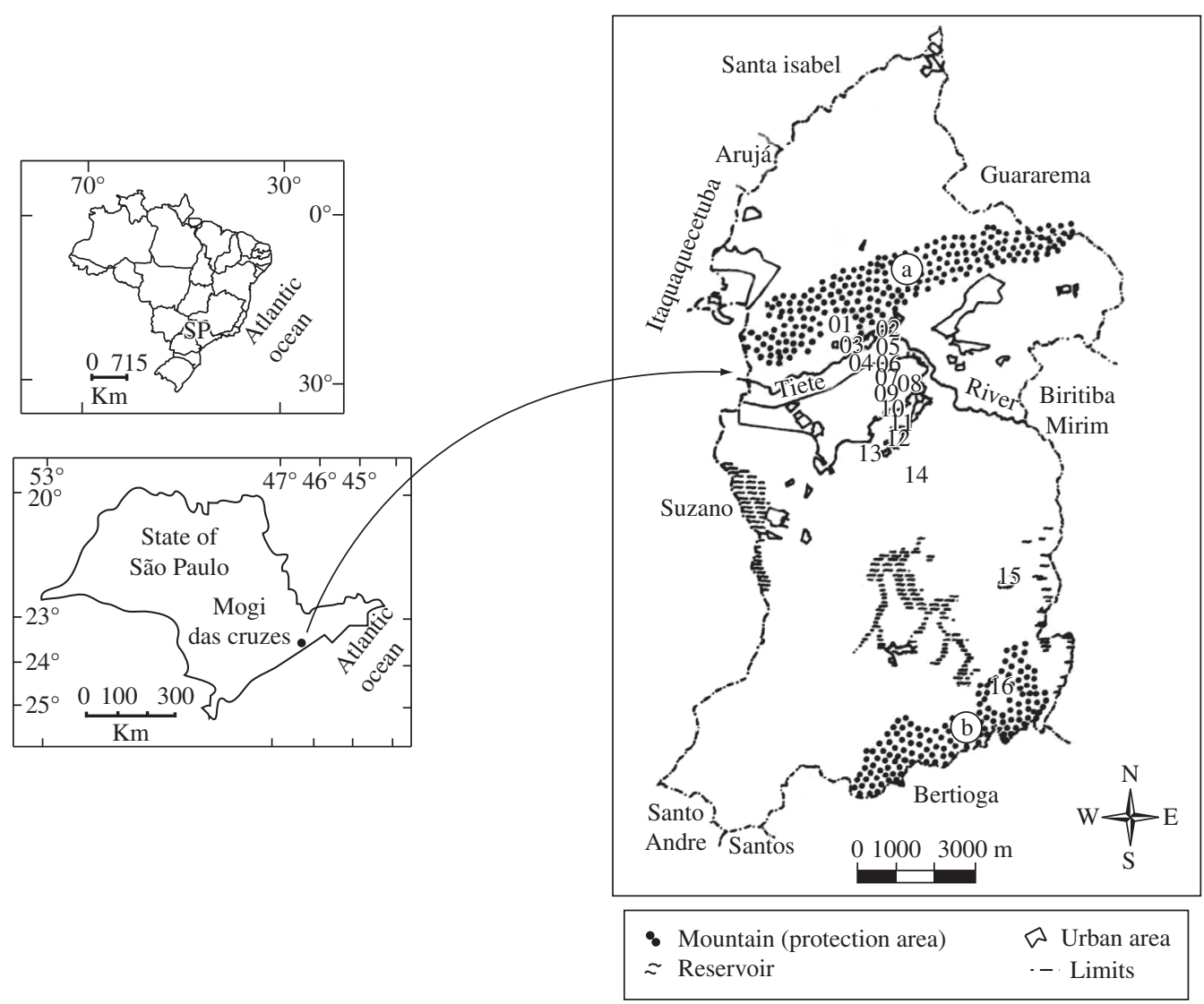

Figure 1. Location of the neighborhoods sampled in Mogi das Cruzes (SP). a) Serra do Itapety; and b) Serra do mar. Neighborhoods: 1) Jardim Aracy; 2) Jardim Rodeio; 3) Jardim Ponte Grande; 4) Mogilar; 5) Vila Industrial; 6) Centro; 7) Remédios; 8) Vila Natal; 9) Mogi Moderno; 10) Conj. Nova Bertioga; 11) Vila da Prata; 12) São Sebastião; 13) Vila Oropó; 14) Vila Moraes; 15) Biritiba Ússu; and 16) Manuel Ferreira.

The number of ant species collected in the urban area studied demonstrates, together with the studies of Fowler et al. (1993), Bueno and Fowler (1994), Delabie et al. (1995), Silva and Loeck (1999) and Piva and CamposFarinha (1999), that tropical urban ecosystems are richer in ant species compared to those in temperate climates. In tropical regions, the availability of food and nesting sites, which are important conditions for the maintenance of the species in a specific locale (Hölldobler and Wilson, 1990), are abundant and generate environments which are propitious for a greater number of species.

Comparing the internal and external areas of the residences, lower species richness (26) was observed inside houses, but the highest abundance $(10,670)$, with the wash area and kitchen being the locales that contributed with the greater number of hits (Figure 3). The inverse was found in the external areas of the houses, with 54 species and 3,747 ants being recorded (Figure 3), of which close to $57 \%$ were collected foraging in the soil and/or vegetation of the gardens and yards of the residences. The Wilcoxon test showed significant differences $(p<0.05)$ between species richness in the external and internal areas of the houses (Figure 4a) and also between the number of individuals collected within each species $(\mathrm{p}<0.05)$ (Figure $4 \mathrm{~b})$. The similarity between species richness in the two areas, calculated using the Jaccard index, was low (0.38). There was a predominance of species known as tramp ants in the interior of the houses, possibly contributing to a higher number of individuals collected, as they are characterized by the recruitment of a large number of worker ants for foraging activities (Bueno and Campos-Farinha, 1999). Tramp ants are species that are intimately associated with human activities, and generally nest in structures built in urban environments (Schultz and McGlynn, 2000). They share characteristics that facilitate their introduction into new environments, such as generalist feeding habits, polygamy, reduced intra-specific aggression, small size, and high recruitment, as well as having a high rate of migration, uni-colonial population, abolition of nuptial flight, and very small workers and queens (Passera, 1994; Holway et al., 2002).

In the internal areas of the residences, the species Tapinoma melanocephalum Fabricius, 1793, 
Ph. megacephala Fabricius, 1793, S. saevissima (F. Smith, 1855) and $P$. fulva (Mayr, 1887) were the most frequent, and also the most abundant, with the exception of $P$. fulva, substituted by Monomorium pharaonis (Linnaeus,

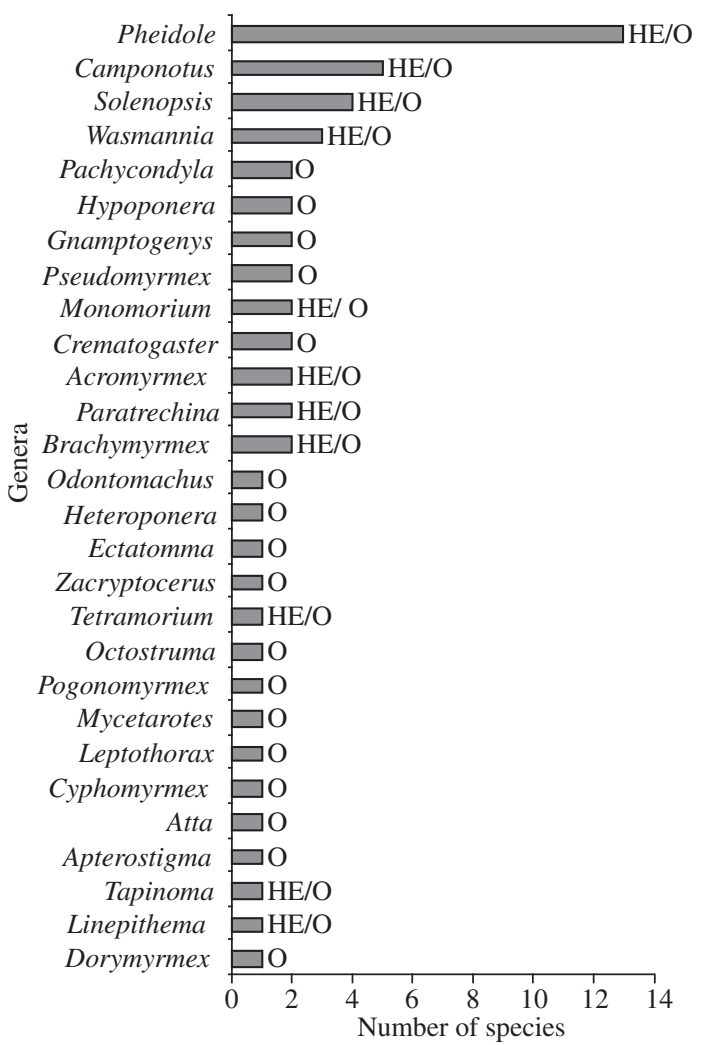

Figure 2. Number of species according to the genera sampled in the household environment (HE) and around the outside of the houses $(\mathrm{O})$, in an urban ecosystem located near areas of Atlantic Rainforest.
1758). In the external areas of the houses, the most frequent species were $S$. saevissima, Ph. aberrans Mayr, 1868, P. fulva and Brachymyrmex sp.4 (Mayr), whereas Ph. megacephala, S. saevissima, T. melanocephalum and Brachymyrmex sp.4 were the most abundant (Table 1).
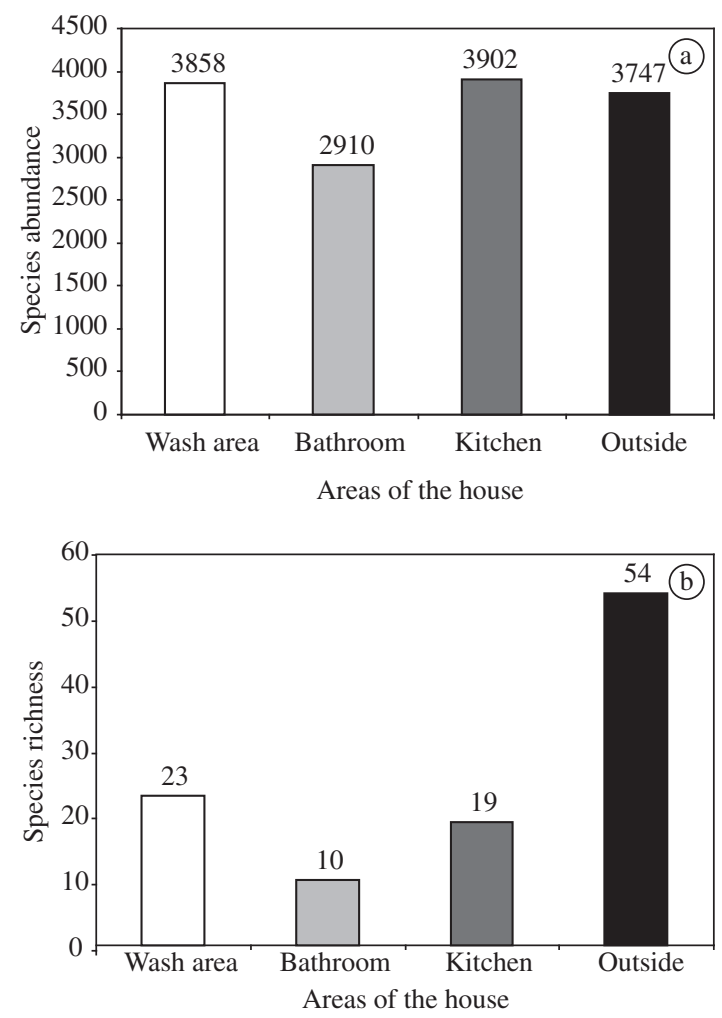

Figure 3. Total number of ants (a) and total number of species (b) sampled according to the locations in the residence.

Table 1. Species with the highest relative frequency and abundance, according to the residential area samples.

\begin{tabular}{|c|c|c|}
\hline Location & $\begin{array}{c}\text { Species } \\
\end{array}$ & Frequency $(\%)$ \\
\hline \multirow[t]{4}{*}{ Household environment } & T. melanocephalum (Fabricius) & 24.46 \\
\hline & P. megacephala (Fabricius) & 15.83 \\
\hline & S. saevissima (F. Smith) & 10.79 \\
\hline & P. fulva (Mayr) & 7.91 \\
\hline \multirow[t]{4}{*}{ Outside the house } & S. saevissima (F. Smith) & 12.39 \\
\hline & P. aberrans (Fabricius) & 7.83 \\
\hline & P. fulva (Mayr) & 7.83 \\
\hline & Brachymymyrmex sp.4 (Mayr) & 7.17 \\
\hline Location & Species & Abundance \\
\hline \multirow[t]{4}{*}{ Household environment } & T. melanocephalum (Fabricius) & 3948 \\
\hline & P. megacephala (Fabricius) & 3582 \\
\hline & Monomorium pharaonis (Linnaeus) & 2238 \\
\hline & S. saevissima (F. Smith) & 1186 \\
\hline \multirow[t]{4}{*}{ Outside the house } & P. megacephala (Fabricius) & 915 \\
\hline & S. saevissima (F. Smith) & 613 \\
\hline & T. melanocephalum (Fabricius) & 312 \\
\hline & Brachymyrmex sp.4 (Mayr) & 280 \\
\hline
\end{tabular}




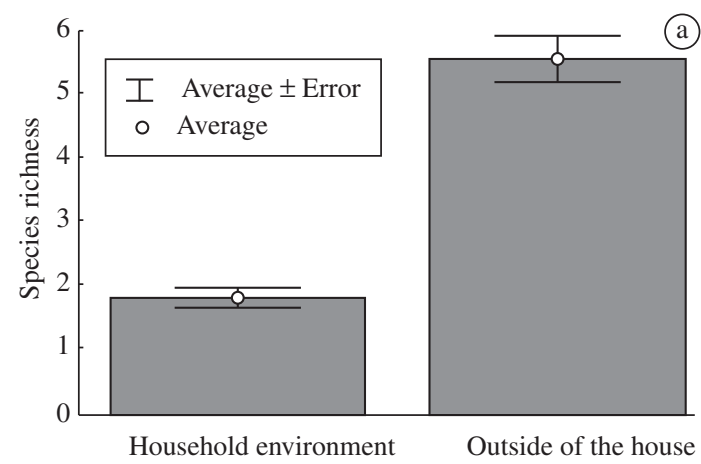

Areas of the house

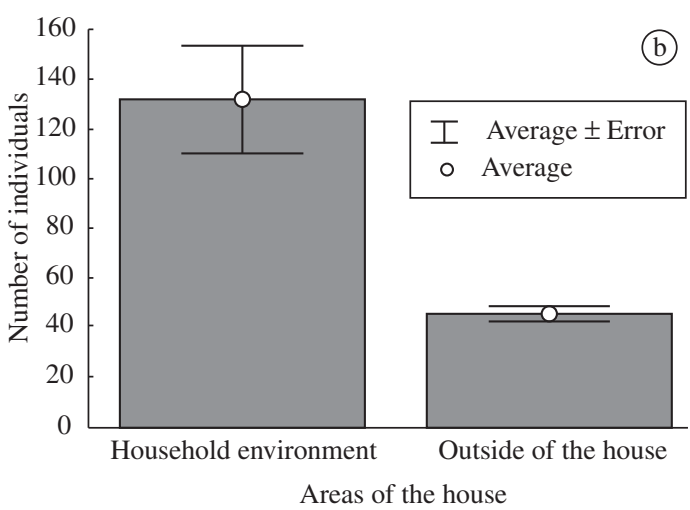

Figure 4. Comparison of species richness a) and the number of individuals per species; and b) in the household environment and around the outside of the houses in an urban ecosystem located near the Atlantic Rainforest.
One can see that the most frequent and the most abundant species were practically the same inside and outside the residences, being the species with the widest geographical distribution (Schultz and McGlynn, 2000), and that they are on the list of the most significant urban ants in southeastern Brazil and southern Bahia proposed by Campos-Farinha et al. (2002).

Since all the ants on this list were collected in different neighborhoods of Mogi das Cruzes, they can be placed in order of importance for this urban area, based on the relative frequency of each one: S. saevissima, T. melanocephalum, L. humile Mayr, 1868, P. fulva, W. auropunctata Roger, 1863, P. longicornis (Latreille, 1802), Ph. megacephala, M. pharaonis and M. floricola Jerdon, 1851. Of these, $P h$. megacephala was almost the unique species collected in Vila dos Remédios and Vila Industrial, which are the oldest neighborhoods of the city.

Due to their behavioral characteristics, the presence of Ph. megacephala may be responsible for the death of native invertebrates, ants in particular (Fowler et al., 1994; Vanderwoude et al., 2000), and they indicate that they are dominant in houses and other environments intensively impacted by humans (Fowler et al., 1994; Delabie et al., 1995). Their negative association with P. longicornis and S. saevissima (Figure 5) has already been reported by Delabie et al. (1995), however their antagonism with $L$. humile as described by Haskins and Haskins (1965), Crowell (1968) and Delabie et al. (1995), could not be verified, as this native species appeared in

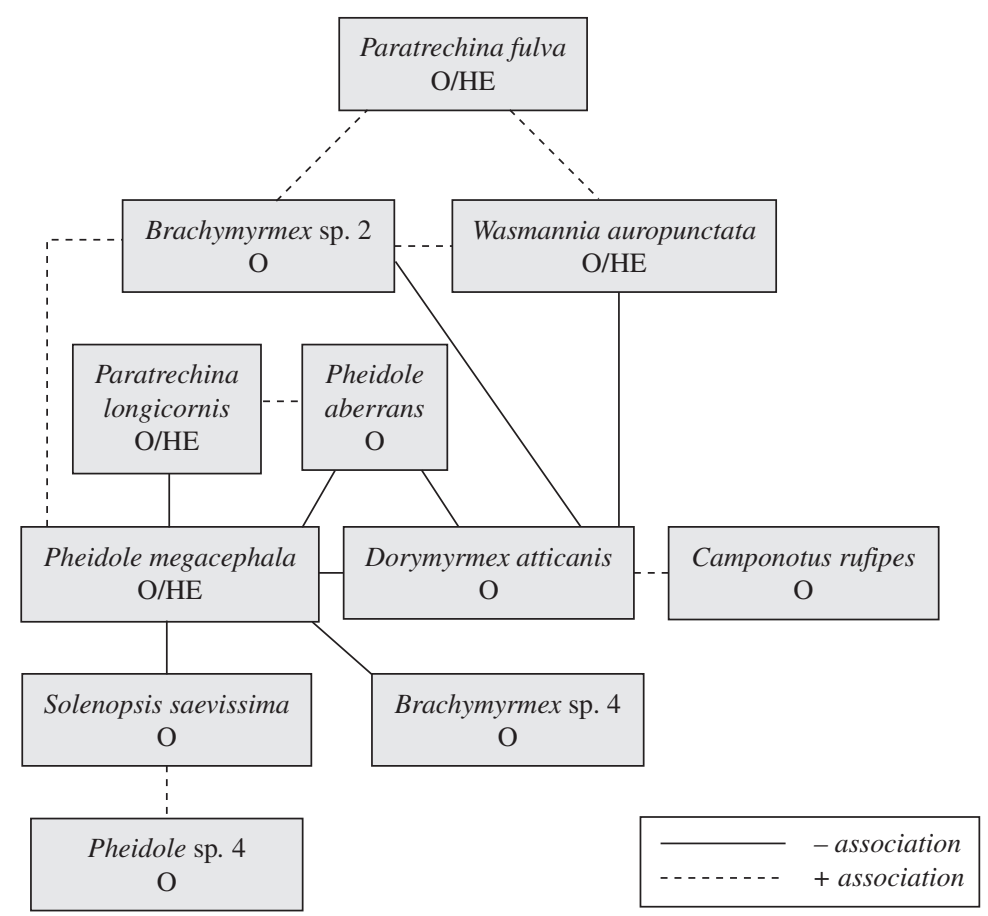

Figure 5. Structure of the ant community in urban areas near the Atlantic Rainforest. Solid and dotted lines indicate significant $(\mathrm{p}<0.05)$ negative and positive associations, respectively. (O: outside of the house; HE: household environment). 
low frequency and abundance even in the neighborhoods where Ph. megacephala was not observed.

Therefore, even though the urban ecosystem studied originated from an environment of the Atlantic Rainforest, and has neighborhoods that are still located very near to this vegetation, one observes, in the interior and exterior of the residences, that the predominant ants are those normally found in an urban environment. Of these species, those that deserve special note include the cryptics (Octostruma rugifera Mayr, 1887) and the generalist predators of the understory (Heteroponera dolo Roger, 1961, Hypoponera sp. 1 and sp. 6 Santschi, 1938, Gnamptogenys sp. 4 Roger, 1863, G. striatula Mayr, 1884, Odontomachus meinerti Forel, 1905, Pachycondyla constricta Mayr, 1883 and P. striata Fr. Smith, 1858). Despite these species being considered typical in the forest environments, their presence in the urban ecosystem may be due to three factors: (1) to the meeting of biotic and abiotic conditions for survival during the process of deforestation and occupation of the area by housing; (2) the continuous replacement of the taxons due to the presence of native vegetation in the surrounding area; and (3) the fact that, according to Yamaguchi (2005), different species can respond differently to the process of urbanization, favoring the survival of some taxons from the Atlantic Rainforest area in the urban area.

Rickman and Connor (2003), working on ants with Lepidoptera, and López Moreno et al. (2003), reported that the greater the population density, the greater the abundance of individuals per species, and the lower the number of species. These results are similar to those obtained in the present investigation, as in the neighborhoods closer to the urban center, which are the most populous, lower species richness and greater abundance of individuals were observed in comparison to the neighborhoods located nearer the mountains, which are less populous. The exception was Vila Oropó, which is a neighborhood that was recently formed and is still sparsely populated, where a greater abundance and one of the highest values of richness, were reported (Figure 6). However, close to $77 \%$ of the total number of individuals observed in this neighborhood were $M$. pharaonis, which is probably the most widely distributed tramp ant in the world (Edwards, 1986).

The greater abundance of individuals per species in the more populous neighborhoods is related to the predominance of the ants known as tramp ants, in the areas inside as well as outside the houses. In the lesser populated neighborhoods, despite the domination of the tramp ants in the areas of the most intimate co-existence with humans, they have not been able to eliminate the native ants from the gardens and yards, even leaving some niches unoccupied that may have been the reason for the high relative frequency found for Brachymymex sp. 4. According to Wetterer and Wetterer (2004), this type of behavior is characteristic of this genus, i.e., the occupation of locales where tramp ants are not yet found.
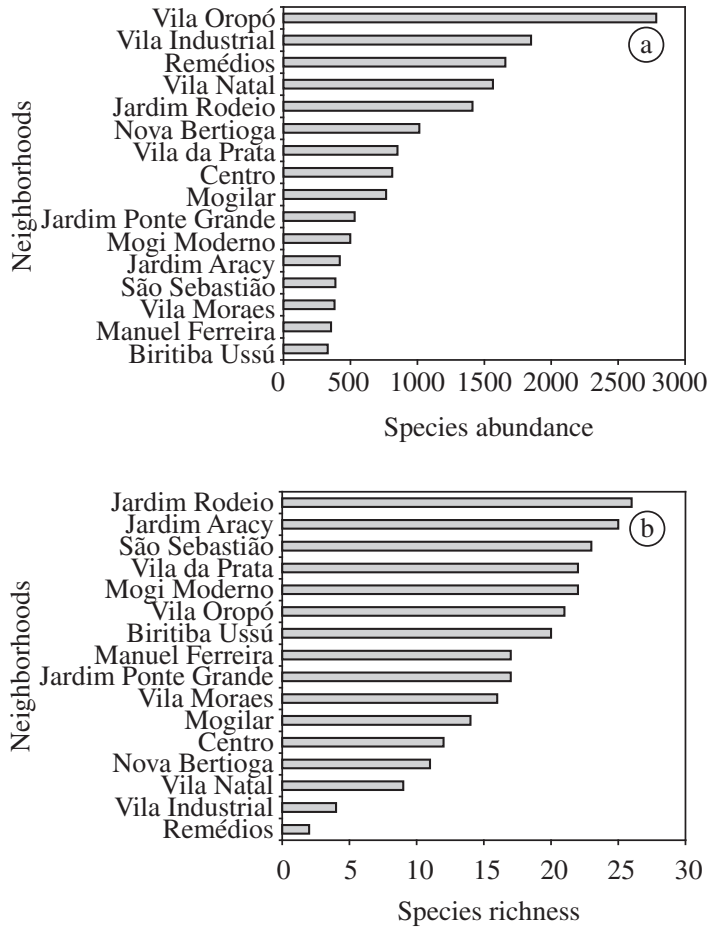

Figure 6. a) Abundance and b) Richness according to the neighborhoods sampled.

Thus, the presence of native vegetation in the yards and gardens of the houses, or of the forest near the neighborhoods, may possibly be allowing the existence in an urban area of some taxa which are characteristic of the forest area, which over time, can generate a positive impact on the maintenance of the biodiversity of this ecosystem.

Acknowledgments - We would like to thank CNPq for the Scientific Initiation scholarship granted to the first author; Dr. Julio Cesar Voltolini for the data analysis; Dr. J.H. Delabie for the valuable comments on the first version of the manuscript; Dr. Rogério R. da Silva do Museu de Zoologia at USP for identifying some species; and FAEP/UMC for the financial support.

\section{References}

BOLTON, BA., 2003. Synopsis and classification of Formicidae. Memoirs of the American Museum Entomological Institute, vol. 71, p. 1-370.

BUENO, OC. and CAMPOS-FARINHA AEC., 1999. As formigas domésticas. In MARICONI FAM. (ed.): Insetos e outros invasores de residências. Piracicaba, SP, FEALQ, p. $135-180$.

BUENO, OC. and FOWLER, HG., 1994. Exotic ants and the ant fauna of Brazilian hospitals. In WILLIAMS DF. (ed) Exotic ants: biology, impact and control of introduced species. Westview Press, Boulder, p. 191-198.

CAMPOS-FARINHA, AEC., BUENO, OC. and KATO, LM., 2002. As formigas Urbanas no Brasil: Retrospecto. Biológico, vol. 64, no. 2, p. 129-133. 
CROOKS, KR. and SOULÉ, ME., 1999. Mesopredator release and avifaunal extinctions in a fragmented system. Nature, vol. 400 , no. 6744 , p. 563-566.

CROWELL, KL., 1968. Rates of competitive exclusion by the Argentine ant in Bermuda. Ecology, vol. 49, no. 3, p. 551-555.

DELABIE, JHC., NASCIMENTO, IC. do, PACHECO, P. and CASIMIRO, AB., 1995. Community structure of houseinfesting ants (Hymenoptera: Formicidae). Fla. Entomol., vol. 78 , no. 2, p. 264-270.

EDWARDS, JP., 1986. The biology, economic importance, and control of the pharaoh's ant, Monomorium pharaonis L. In VINSON SB. (ed.) Economic impact and control of social insects. New York: Praeger Publishers, p. 257-271.

EICHLER, WD., 1978. Die verbreitung der Pharaoameise in Europa. Memor. Zool., Wroclaw, vol. 29, p. 31-40.

FOWLER, HG., SCHLINDWEIN, MN. and MEDEIROS MA., 1994. Exotic ants and community simplification in Brazil: a review of the impact of exotic ants on native ant assemblages. In WILLIAMS DF Exotic ants: Biology, Impact, and Control of Introduced species. Boulder Westview Press, p. 151-162.

FOWLER, HG., ANARUMA-FILHO F. and BUENO, OC., 1993. Seasonal space usage by the introduced pharaoh's ant, Monomorium pharaonis (L) (Hym., Formicidae), in institutional in Brazil and its relation to other structural ant species. J. Appl. Entomol., vol. 115, no. 4, p. 416-419.

HASKINS, CP. and HASKINS, EF., 1965. Pheidole megacephala and Iridomyrmex humilis in Bermuda- equilibrium or slow displacement? Ecology, vol. 46, no. 5, p. 736-740.

HÖLLDOBLER, B. and WILSON, E., 1990. The ants. Harvard University Press Cambridge, Massachusetts. 732p.

HOLWAY, DA., LACH, L., SUAREZ, AV., TSUTSUI, ND. and CASE, TJ., 2002. The causes and consequences of ant invasions. Annu. Rev. Ecol. Syst., vol. 33, p. 181-233.

LOPES-MORENO, IR., DIAZ-BETANCOURT, M. and LAND, TS., 2003. Insectos socials en ambientes antropizados: las hormigas de la ciudad de Coatepec, Veracruz, Mexico. Sociobiology, vol. 42, no. 3, p. 605-621.

LUCK, RF. and DAHSTEN, DL., 1974. Natural decline of a pine needle scale (Chionaspis pinifoliae (Fitch)) outbreak at South Lake Tahoe, California, Following cessation of adult mosquito control with malathion. Ecology, vol. 54, no. 4, p. 893-904.

MAGURRAN, AE., 1998. Ecological diversity and its measurement. Princeton University Press, New Jersey. 179p.
McINTYRE, NE., RANGS, J., FAGAN, W.F. and FAETH, SH., 2001. Ground arthropod community struture in a heterogeneous urban enviroment. Landsc. urban plan,. vol. 52, no. 4, p. $257-274$.

PASSERA, L., 1994. Characteristics of tramp species. In WILLIAMS DF. (ed.) Exotic ants: Biology, Impact, and Control of Introduced species. Boulder Westview Press, p. 23-43.

PIVA, A. and CAMPOS-FARINHA, AEC., 1999. Estrutura de comunidade das formigas urbanas do bairro da Vila Mariana na cidade de São Paulo. Naturalia, vol. 24, p. 115-117.

RICKMAM, JK. and CONNOR, EF., 2003. The effect of urbanization on the quality of remnant habitats for leaf-mining Lepidoptera of Quercus agrifolia. Ecography, 26, no. 6, p. 777-787.

SCHULTZ, TR. and McGLYNN, TP., 2000. The interactions of ants with other organisms. In AGOSTI D., MAJER JD., ALONSO, LE. and SCHULTZ TR. (eds) Ants: standard methods for measuring and monitoring biodiversity. Smithsonian Institution Press, London, p. 35-44.

SIEGEL, S., 1975. Estatística não paramétrica (para as ciências do comportamento). São Paulo: McGraw- Hill. 350p.

SILVA, EJE. and LOECK, AE., 1999. Ocorrência de formigas domiciliares (Hymenoptera: Formicidae) em Pelotas, RS. Rev. Bras. de Agrociência, vol. 5, no. 3, p. 220-224.

SUAREZ, AV., BOLGER, DT. and CASE, TJ., 1998. Effects of fragmentation and invasion on native ant communities in coastal southern California. Ecology, vol. 79, no. 6, p. 2041-2056.

VANDERWOUDE, CL., LOBRY DE BRUYN, LA. and HOUSE, PN., 2000. Response of an open-forest ant comunity to invasión by the introduced ant, Pheidole megacephala. Austral Ecol,. vol. 25, no. 3, p. 253-259.

WETTERER, JK. and WETTERER, AL., 2004, Ants (Hymenoptera: Formicidae) of Bermuda. Fla. Entomol., vol. 87, no. 2 , p. $212-221$

YAMAGUCHI, T., 2004. Influence of urbanization on ant distribution in parks of Tokyo and Chiba City, Japan. I. Analysis of ant species richness. Ecol. Res., vol. 19, no. 2, p. 209-216.

-, 2005. Influence of urbanization on ant distribution in parks of Tokyo and Chiba City, Japan. I. Analysis of species. Entomol. Sci., vol. 8, no. 1, p. 17-25. 